\title{
Exploration of the Audit Independence ${ }^{*}$
}

\author{
Yu-ying Yu ${ }^{1}$, Xiu-li Zhu ${ }^{\dagger 2}$, Fang-xing $\mathrm{Fu}^{3}$ \\ ${ }^{1}$ The Business School of The China University of Political Science and Law, Beijing, China \\ ${ }^{2}$ Nanjing University of Finance and Economics, Jiangsu Province, China, Shanghai Jiaotong University, Shanghai, China \\ ${ }^{3}$ AVIC International Aero-Development Corporation, Beijing, China \\ yyy6281@163.com,xlzhuzhu@163.com, fufangxing@avic-intl.cn
}

\begin{abstract}
Different from the two kinds of audit requirements proposed by agency theory, the practical audit mode needs to guarantee the audit independence. But the stakeholders of the audit business make current protection measures for the independence of the audit from their own view. From the systems perspective, we suggest on the basis of considering the audit process that: (1) we should improve the information transparency before the manager and the auditor make the audit contract by the construction of enterprises. (2) we should strengthen the publicity when we hire or dismiss the audit firm.(3)the audit association provide professional service for the board of directors, in particular the board of audit committee. (4)we should introduce a third party arbitration to resolve accounting divergence between the auditor and manager (5)we should expand the channels of supervision, and strengthen the execution of the punishment.
\end{abstract}

Index Terms - Audit independence, Systematic process, The third party

\section{Introduction}

Since the birth of the auditing, auditor independence has been all widely concerned. Auditor independence has experienced from the industry self-regulation stage to the regulator phase. The regulated areas include the principal auditor tenure rotation, the rotation of the audit firm, the separation of auditing and consulting business, and so on. In particular, the Sarbanes bill proposed the establishment of public corporation accounting oversight committee (PCAOB). As a special supervision agency, the PCAOB is responsible for the audit of listing Corporation. Although the auditor's external supervision measures continue to strengthen, but the audit frauds are still occurring. In fact, as a regulator, the government has the need of auditor independence. At the same time, both the supply and demand of audit services-both the audit firms and the enterprises have also the need of the auditor independence, which will ensure the independence of auditor for their own interests.

\section{The Generation of Auditor Independence}

The rapid development of the independent audit derives from the separation of ownership and management. Jensen \& Meckling (1976) interpreted the generation of audit requirements from the perspective of the principal-agent relationship. Since the principal and agent have different utility functions, and the economic man hypothesis, the goal of the agent is to pursue maximum utility. As a result, it is impossible for the management to always achieve the maximum benefit of the principal, so that the value of the enterprise is more than the value of the absence of the external equity. The difference between two forms of enterprise value is the agency cost. In the absence of supervision and assurance activities, the agency cost is the money loss of the principal's welfare, which is caused by the deviation between the decision-making of the maximization of the principal's welfare and the agent's decision, which is called the residual loss. In order to reduce the deviation between the principal and the agent, the principal develops appropriate incentives for the agent, and limits the exception of the agent activity. The cost of these activities is called monitoring costs. In order to realize utility maximization, the agent will guarantee that he will not take some actions which would harm the principal or ensure that the principal will be compensated if the agent harms the interests of the principal. The expenses arising from such acts are called bonding costs. The occurrence of the supervision cost and the bound cost will increase the value of the enterprise which has only the surplus loss. That is to say, the use of the supervision activity and the guarantee activity also accords with the cost-benefit principle.

The management compensation contract is actually a kind of supervision activities designed to protect their own interests by the outside shareholders. In this contract, the series of financial measures are usually included that used to measure the performance of the managers and to decide how much money is paid to the manager according to the indicator. Of course, the financial report also has an important role that maintains the agency relationship between the managers and outside shareholders, because the financial report that presents the results of the managers' behaviour is used to inspect the enterprise performance and to decide whether or not to continue investment by the outside shareholders.

According to the financial report of the chain, the managers are responsible for the preparation of financial reports. Due to the managers' self-interest behaviour and the existence of asymmetric information, the financial statements are not credible. The external shareholders have the motivation to hire the external auditors who will review the financial reports prepared by the managers in order to supervise the managers. In this paradigm (Paradigm I ), the shareholder and the external auditors will reach the audit agreement. The purpose of audit is derived from the interests of outside shareholders. At the same time, the shareholders pay auditor

\footnotetext{
* Supported by Science Foundation of Ministry of Education of China for Young Scholars (14YJC630211), China Postdoctoral Science Foundation (2013M531182) and Project No.10814311.

${ }^{\dagger}$ Corresponding author.
} 
audit fees. The audit fees are the supervision cost. In this case, if the managers do not collusion with the external auditor in advance, the external auditor has natural independence from the perspective of economic interests.

As for the managers, especially the responsible managers, they expect their own behaviour to be reflected realistically and then get their rewards. When the net income obtained from the audit report is greater than the net income of the report without audit, the managers will also have the incentive to hire the auditor to review the financial report in order to enable outside shareholders to the trust the preparation of financial statements. In this paradigm (Paradigm II), the managers and the external auditors will reach the audit agreement. The purpose of the audit is also to prove that the prepared financial statements are credible. Different from the Paradigm I, the sponsor of the audit is managers. The managers pay auditor audit fees that are the bonding expenditures. In this case, in order to make the third party - the shareholder trust audit results, the auditor must reveal how to guarantee the independence of the audit process.

In real life, the external equity of the company we have seen is often scattered. We have no reason to doubt that the contract cost made by scattered outside shareholders and the auditor is far more than the contract cost singed up by the managers and the auditor. This is why the managers hire the auditor, not external shareholders hire the auditor in the real word. So, the mangers and the auditors will conclude the audit contract which triggered the formation of a new principalagent relationship. The manger is the principal rather than the agent in the audit contract. The auditor is the agent. It is clear for the manager that the outsider shareholders also need financial reporting not only to make investment decisions but also to monitor their behaviours. To some extent, the behaviour of the guarantee is derived from the supervision of the external shareholders. The actual user of the audit report is the external shareholder. The purpose of the audit is still to make investors trust financial statements. However, it is different from the paradigm I, the managers rather than the shareholders are responsible for hiring the auditor. It is also different from the paradigm II, the audit fees come from the resources of the audited company, not of the managers, but the managers decide the amount of audit fees. Since the audit contract is made by the managers and the auditor, and then the managers pay audit fees to the auditor, the economic dependence of the auditor to the manager thus will appear. And the empirical results (such as DeAngelo, 1981) also show that the auditor has the economic dependence of the clients so that the auditor independence has been undermined ${ }^{[2]}$ and ultimately, the auditor's financial report is lack of reliability, which ultimately leads to the external shareholders believe that the audit report is lack of credibility. As a result, the intention of the manager to hire the auditor can't be achieved.

Other empirical results also show that the results of the four big audit firms are more credible than the results of the others due to the reputation and industry expertise of the four big audit firms. Those companies with large scale and good performance will be more inclined to hire the four big audit firms in order that they can inform the investors that the financial report is more reliable. There are a lot of factors to be considered in order to get high quality audit report. But lots of audit failure cases told us that the auditors who lost their independence would be easier to issue the audit report with low quality, and the auditor would be thus more likely to encounter litigation filed by the investors. Therefore, auditor independence is the guarantee of the realization of the audit contract and the liberation of auditor liability.

\section{Guarantee Measures for Audit Independence}

According to the hypothesis and information asymmetry, the auditors can't guarantee their independence because of the principal-client relationship between the managers and the auditors in the real audit business. The cases of audit failure also prove that the economic dependence of the auditor is detrimental to its independence. This approach that the reliability of the audit report is ensured only by the auditor's moral conscience in the absence of the external forces is unlikely to achieve of the Pareto optimal of the economics. The audit business involves the subject of audit participantsthe enterprise and the auditor, and the audit supervisor of the capital market -the government. So how to guarantee the audit independence, this paper will analyse from three aspects of the enterprise, the auditor and the government.

The big issue confronting the enterprise is how to make the external shareholder to trust the audit report. The most direct solution to the problem is that the external shareholders directly participate in the formulation or execution of the audit contract. However, due to the large number of shareholders, the method will generate a high transaction costs. It isn't in accordance with the cost-effective principle. This is why the shareholders are not directly involved in the conclusion and implementation of the audit business contract in the real word. The current use of the audit committee in the corporate governance structure is an alternative method. The introduction of the third party participation in the implementation of the audit contract is the next-best thing.

As Birkett (1986) said, the establishment of the audit committee is essentially to protect the independence of the external auditor ${ }^{[3]}$. However, if the audit committee members are not completely independent of the administrator, the audit committee can't protect the independence of the external auditor ${ }^{[4]}$. It is also because of the importance of the independence of audit committee members, the blue ribbon Committee established by the New York stock exchange and the national association of securities dealers in the United States presented that the members of the audit committee should be independent of the manager in the first proposal. The domestic and foreign empirical results also show that when the auditor has a conflict with management, the audit committee with stronger independence is more effective in supporting auditors to insist on their own correct judgments. The conclusion that is the positive influence of the independence of the auditor on the quality of the audit has nothing to do with the degree of capital market development and the enterprise nature. The independence of the audit committee means that they can supervise the management of the management according to the interests of the shareholders, 
and then can protect the independence of the auditor..Finally, the auditor committee will realize the balance mechanism in the corporate governance structure.

As the third party, the auditor is engaged in the audit work. From the date of its birth, independence has become a unique feature of the audit industry. Mauls and Sharaf said that the auditor keep independence is very important for the audit business in the book named "the philosophy of auditing". Independence is indispensable to the auditing standards, because the auditor's responsibility is to express an opinion on the financial statements based on the audit evidence. In order to fulfil the independent check-up duty, the auditors must be independent of the principal. Otherwise the audit opinion will lose any sense. The book also mentions the auditor's reputation and the role can be maintained, largely depends on the performance of the auditor's responsibility. That is to say auditor independence in relation to the survival of auditor industry. When the auditor is financially dependent on the manager, no one can believe that the auditor obtain the audit fees and at the same time keep the completely independent as the third party, especially when the auditor is also related to the consulting services. Independent auditors should work under the strict supervision of the public. That is to say, it is not enough that the auditor thinks he is independent and makes the client believe he is independent. If we don't take the necessary measures to guarantee the essentially independence and the independence of the appearance, the Securities Exchange Commission is hard to recognize the independence of auditor in many cases ${ }^{[5]}$. This indicates that it is difficult for the stakeholders as the third party to recognize the independence of the auditor in the future ${ }^{[5]}$. This is why the auditor will voluntarily form the audit association that actively develops industry standards and new audit methods used to meet new audit environment.

The presence of the audit committee and the association of auditors is the product of the market. But the market as the invisible hand is not always the proper command. For example, there will be no efficiency results in the public product market, the market with the externality, the imperfect competition and the asymmetric information market, that is, the market failure. Due to the information asymmetry existing in the audit market, on the one hand, the manager who has the advantage of information will understand more about the company than the auditor. On the other hand, the manager will have incomplete information of auditor specialization degree (Casterella et al., 2004) ${ }^{[6]}$. The government has to amend the market failure because of the relationship of fiduciary responsibility so that the government can establish and maintain the market rules. There are two ways in which the government can improve the allocation of market resources. The one way is that the government can directly provide goods and services. The other method is that the government can formulate and implement laws or regulations that change the market results. The audit service is not public products, so it's impossible for the government to provide directly the audit service, but to develop the relevant laws and regulations for the audit market. the use of the relevant laws and regulations, the audit market regulation. This is also what we have seen in reality, the governments have worked out the audit standards and audit system that especially pay more attention to the responsibility and independence of the auditor.

\section{Proposals for Improving the Auditor Independence}

According to the agency theory, whether the manager or the shareholders employ auditor, it can reduce the loss of agency costs. But due to dispersion of outside equity, real life more is managers employ auditors, and from the enterprise paid audit fees, managers and auditors in the principal-agent relationship is formed on the basis of the principal-agent relationship between managers and shareholders of the original. The ultimate goal of the audit is to make the shareholders trust the financial statements, which will produce the independence of the auditor. However, due to the decentralization of external ownership, the auditor in real life is hired by the auditor, and the audit fee is obtained from the enterprise. The principalagent relationship between the manager and the auditor is formed on the basis of the principal-agent relationship between the managers and the shareholders. The ultimate goal of the audit is to make the shareholders trust the financial statements, which will produce the independence of the auditor. The personnel involved in the audit business, includes the management who prepares financial statements, the auditor who provide the assurance services, the shareholders who is the service object of the audit business, and the government who regulates the audit market. For the interests of the parties, the four groups have their own measures to improve the auditor independence. The manager and shareholders in the company set up the audit committee to support the auditor to make a correct judgment. The auditors spontaneously establish the audit association to develop the relevant industry standards and propose a new audit method to assist the auditor to maintain and enhance the auditor independence. The government develops the relevant laws and regulations and supervises the auditor behaviour from the perspective of law.

Audit is a systematic process, involving the conclusion of the audit contract, the implementation process of the audit, the audit supervision and review afterwards. The existing parties of audit business establish the protection measures to keep the auditor independence in the audit phase that they are concerned. The all stages of the audit affect each other and can't be separated. Therefore, we should combine organically the requirements and guarantee measures to audit independence of the four parties, and ultimately improve the existing audit quality. Specifically, we can achieve the purpose from the following five dimensions.

The information is always asymmetric in the contract signing process. The degree of information asymmetry directly produces moral hazard and adverse selection, which affect the fulfillment of the contract. The audit association who is relatively dependent from the supply and demand of the auditor industry relative to the audit service can take advantage of its advantages to play a role in the way of building auditor database and enterprise database. The auditor database can include audit firm's basic situation, establishment and execution of auditing system, the audit client's industry distribution, financial misdeeds and punishments of the audit 
firm, the basic information and auditing experience of certified public accountant and so on. The enterprise database should consist of the basic information of the company and the manager, violation records and penalties, the audit firm and the signature accountant including the unlisted period, reason for the change of audit firm etc. As a result, the company can make a preliminary understanding of audit firms by the auditor database. And the company can select the audit firms according to its own needs and evaluate effectively the auditor abilities. Thus, it is beneficial to the board of directors, the board of supervisors, the shareholders and the external stakeholders of the stakeholders to supervise the manager, and reduce the joint fraud between the manager and the auditors. Similarly, the auditors will obtain the business information by browsing the enterprise database before the conclusion of the audit contract, in order to determine whether to provide the audit services, and to deal with the factors that affect audit independence.

As the government improve procurement efficiency and fairness through open tender, the company can also take open tender to hire firm audit, and the audit firms can determine the auditors who are engage in the audit service by the competitive appointment way. These measurements can reduce the possibility of collusion between the management and audit firms or the auditors to ensure the independence of the audit firms and the auditors from fountainhead. According to the existing company law, when the meeting of shareholders, the general meeting of shareholders or the board of directors decides to vote on the dismissal of the existing audit firm, the audit firm has the right to state its opinion. But only this is not enough, because the accountants and managers are made the interpretation of firing events from their own perspective. The shareholders and directors of the company may not have the knowledge of the judgment, especially meeting the professional issues of accounting and audit. So it is necessary to introduce the independent third party who should explain the professional issues to the participants. The person with voting right is exercised under the real fully informed, can effectively avoid that the audit firm loss the audit independence because of the threat of dismissal.

The audit association who serve the audit firms and the auditors should also provide the necessary assistance to the board of directors, in particular, the members of the audit committee. The audit association should propose the audit firm how to regulate the independence of the audit, provide regular training for the auditors about the changed guidelines regulations that also include the new emergence of the fraud means and how to screen these methods, and how to deal with the management's "unreasonable" requirements or the temptation. In addition, the audit association can set up a special service organization who can handle queries for the board of directors, especially members of the audit committee and provide them audit related knowledge training and consultation, so that the board of directors, especially the audit committee can really assist the audit firm or the auditors.

The manager has always objection to the suggestion of accounting adjustment or the conclusion proposed by the auditors in the audit process. When they fail to reach an agreement about accounting divergence, the manager will start firing mechanism. In this case, the audit firm and the auditors may loss their independence to obtain economic benefits. We can draw on the practice of contract law. When there are disputes between the two parties, they can introduce independent third party who uses conciliation, mediation, or arbitration to settle warranty disputes. The third party may be the government's relevant regulatory or the audit association. Of course, the third party arbitration must be fair, fair, open, and have the ability to arbitration. The behaviour of the manager and the auditors is also examined in the process of arbitration. Once the arbitration institution discovers any problems in the audit process, it has the right to report to the relevant regulatory authorities. The regulatory authorities make the appropriate penalties according to the seriousness of the situation. The reasons, results and issues identified in the course of the third party arbitration, the behaviour of the manager and the auditor will be recorded in the enterprise and the auditor database. Therefore, the arbitration mechanism can not only ease the auditor's weak position, but also can play a potential deterrent to the auditor and manager, and provide a channel for the supervisor.

\section{Conclusion}

Audit firms will generally accept the inter industry review, but the industry review is a mere formality because of the mutual checks. And the government regulatory agencies usually make a punishment after a long time of illegal incident. The existing penalty cases show that the punishment isn't enough, and the supervision isn't realized in a very real sense. As the economic man, the auditor will maintain the independence of the audit as the "economic man" only when losses without enough independence outweigh the benefits keeping the independence. The losses are joint probability combined the Detection probability of losing independence with the corresponding degree of punishment. Therefore, the regulators can check the audit report that isn't limited to the annual audit report under the assistance of the audit association at irregular intervals. The results should be announced by the government regulators to the public. And the regulators should make the effective penalties for violations and penalties, and increase the punishment level. So the purpose of ex ante warning and ex post supervision is realized.

\section{References}

[1] Michael C. Jensen, William H. Meckling, "Theory of the firm: managerial behavior, agency costs and ownership structure", Journal of Financial Economics,1976,pp.305-360.

[2] DeAngelo,L., "Auditor independence, 'low balling' and disclosure regulation”, Journal of Accounting and Economics ,1981,pp.113-127.

[3] Birkett, B.S. "The recent history of corporate audit committees [J]. The Accounting Historians Journal (13),1986,pp.109-124.

[4] Joseph V. Carcello, Terry L. Neal, "Audit committee composition and audit reporting", the Accounting Review,2000,pp.453-467.

[5] P.K.Mauts and H.A.Sharaf, Wen Shuo et al (translater), "The philosophy of auditing, China business press, 1990,pp.270-306.

[6] Jeffrey R. Casterella, Jere R. Francis, Barry L. Lewis, Paul L. Walker, "Auditor industry specialization, client bargaining power and audit pricing", Auditing: a Journal of Practice and Theory,2004,pp.123-140. 